\title{
Geochemistry and pollution status of surface sediments of Loktak Lake, Manipur, India
}

\author{
Bhagita Mayanglambam $^{1} \cdot$ Siva Siddaiah Neelam ${ }^{1}$
}

Received: 6 August 2020 / Accepted: 18 November 2020 / Published online: 28 November 2020

(c) Springer Nature Switzerland AG 2020

\begin{abstract}
Surface sediments $(n=29)$ from Loktak Lake, the largest freshwater lake in northeastern India, were studied for geochemistry, mineralogy and the heavy metal pollution of the lake sediments was assessed. The XRD spectra of bulk sediments showed the dominance of quartz and clay fractions showed the dominance of illite and chlorite. The major oxides consist dominantly of $\mathrm{SiO}_{2}, \mathrm{Al}_{2} \mathrm{O}_{3}$ and $\mathrm{FeO}$ with low concentrations of $\mathrm{K}_{2} \mathrm{O}, \mathrm{Na}_{2} \mathrm{O}$ and $\mathrm{CaO}$. The depletion of $\mathrm{CaO}, \mathrm{Na}_{2} \mathrm{O}$ and $\mathrm{K}_{2} \mathrm{O}$ compared to upper continental crust, post-Archean average shale and North-American shale composite indicated moderate to strong weathering, recycling of the source rock and their removal during transportation. The chemical index of alteration values (76.86-84.98) also suggested moderate to extreme chemical weathering of the Loktak Lake catchment

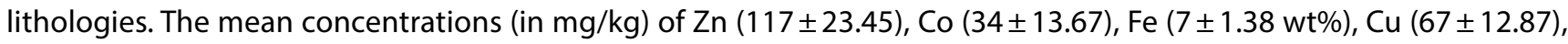
$\mathrm{Cr}(282 \pm 45.25)$ and $\mathrm{Ni}(194 \pm 30.12)$ are about 2-4 times higher than that of the upper continental crust, except for $\mathrm{Mn}$ $(425 \pm 168.99 \mathrm{mg} / \mathrm{kg})$ and $\mathrm{Pb}(17 \pm 7.47 \mathrm{mg} / \mathrm{kg})$. The heavy metal concentrations follow the trend of $\mathrm{Fe}>\mathrm{Mn}>\mathrm{Cr}>\mathrm{Ni}>\mathrm{Zn}$ $>\mathrm{Cu}>\mathrm{Co}>\mathrm{Pb}$. The assessment of heavy metal pollution using enrichment factor, geo-accumulation index and modified degree of contamination suggested non-contamination to moderate contamination of sediments. According to sediment quality guidelines, the sediment-dwelling biota could be affected by the higher concentrations of $\mathrm{Ni}$ and $\mathrm{Cr}$. The mean-effect range median-quotient suggests medium-high to high potential of the effects of heavy metal pollution. The uniformly higher concentration of heavy metals in general and $\mathrm{Ni}$ and $\mathrm{Cr}$, in particular, indicated the dominance of natural (ophiolitic) sources with no or little, if any, anthropogenic influence.
\end{abstract}

Keywords Surface sediments · Geochemistry · Pollution assessment · Loktak lake

\section{Introduction}

Freshwater lakes are often contaminated with various pollutants since they are the receiving end of rivers, streams, run-offs and other waste discharges. Regardless of whether the origin is natural or anthropogenic, the pollutants, after entering the aquatic system, have a high affinity toward sediments. Sediments are heterogeneous assemblages of several sorbent phases such as organic matter, oxides, sulfides, carbonates and clay or silt minerals [74]. Being the source and sink of pollutants derived from catchment weathering and anthropogenic activities such as untreated urban wastes, transport, industries and agricultural wastes [7], they are used to assess the health status of aquatic ecosystems in several studies [19, 73]. During chemical weathering and soil formation processes, labile feldspars are degraded from source rocks to secondary clay minerals and labile cations $\left(\mathrm{Ca}^{2+}, \mathrm{Na}^{+}, \mathrm{K}^{+}, \mathrm{Fe}^{2+}\right.$

Electronic supplementary material The online version of this article (https://doi.org/10.1007/s42452-020-03903-8) contains supplementary material, which is available to authorized users.

Bhagita Mayanglambam, beita.devi@gmail.com; Siva Siddaiah Neelam, nssiddaiah@gmail.com | 'School of Environmental Sciences, Jawaharlal Nehru University, New Delhi 110067, India. 
and $\left.\mathrm{Mg}^{2+}\right)$ are selectively leached relative to hydrolysate constituents $\left(\mathrm{Al}^{3+}\right.$ and $\mathrm{Ti}^{4+}$ ) [53]. Geochemical weathering alters rock mineral compositions depending on factors such as climate, biological activity, parent material, topography, duration of the weathering processes, rate of alteration, etc. [6, 49]. Quantitative estimation of the chemical weathering of silicates such as the chemical index of alteration $(\mathrm{CIA})$ is widely used to interpret the weathering history of sediments $[50,53,68]$. It is a measurement of the proportion of secondary aluminum clay minerals to primary silicate minerals such as feldspars [50]. ClA value for average shale ranges from 70 to 75 reflecting values of muscovite, illite and smectite thus indicating a large proportion of clay minerals [10], while intensely weathered residual rocks forming kaolinite and gibbsite have CIA values approaching 100 [50]. The CIA value of 78.74 of Renuka Lake sediments indicated moderate weathering at the source [11]. Sediment texture, mineralogical composition and physico-chemical transport influence the distribution and accumulation of pollutants in sediments [74]. Most surface water sediments are derived from surface erosion and comprise a mineral component, which arises from the erosion of bedrock [18]. The chemical composition of sediments depends on its contents of quartz and clay fractions which is related to grain size, with $\mathrm{Al}_{2} \mathrm{O}_{3}$ increasing toward finer sediments (clays) and $\mathrm{SiO}_{2}$ toward sands [10]. The knowledge of mineralogical compositions of a lake basin helps to understand the genesis of sediments, transport mechanisms and the nature and intensity of the weathering process within the watershed, etc. [34].

Among the pollutants, heavy metal is a worldwide problem that poses a potential threat to the aquatic ecosystem. They get accumulated into sediments through complex mechanisms of adsorption depending on the characteristics of adsorbed compounds and the sediment matrix [7]. Lake Hamahara of Japan has no industries in its catchment area and no known point sources for metal enrichment in the lake sediments and hence the metals are likely to be housed in the sediment matrix, with additional modifications depending on the sediment redox conditions, anthropogenic sources and surface soil erosion [3]. The deposited metals are released into the overlying water in response to chemical, biological and other physical disturbances [22]. Their non-biodegradable, persistent and irreversible characteristics play a critical role in different trophic levels of the food chain due to bioaccumulation and toxicity [72]. Heavy metals in aquatic systems are present as dissolved ions, complexes, suspended and colloid ions [2]. Upon entering the aquatic system, they have a high affinity to get adsorbed on the fine-grained sediments and consequently pose a threat to aquatic biota particularly the sediment-dwelling organisms [74]. The geochemical analysis of sediments such as enrichment factor and geo-accumulation index are commonly used tools to assess heavy metal pollution $[9,27,60,72]$. The pollution level in lake sediments is also addressed by comparing with sediment quality guidelines $[7,27,52]$. Therefore, with the increasing anthropogenic pressure on inland freshwaters, analysis of sediments is of utmost importance concerning their pollution status and in turn, evaluates the quality of the aquatic ecosystem [48].

Several studies on freshwater lake sediments focus on the environmental concerns of heavy metal contamination. Chakrapani [8] studied the sediment geochemistry of Himalayan Lakes such as Nainital, Bhimtal, Sattal and Naukuchiatal and found the influence of varying degrees of natural and anthropogenic activities on these lakes. Nasser Lake sediments of Egypt had low values of heavy metal pollution indices indicating low human activities in and around the lake [18]. Increased heavy metal pollution of Renuka Lake sediments was derived from human interference such as domestic effluents and untreated sewage discharge [11]. Manasbal Lake sediments had low to moderate pollution of heavy metals which were attributed to anthropogenic inputs such as agricultural run-off, domestic household sewage and land run-off [36]. Jeelani and Shah [28] reported on $\mathrm{Zn}, \mathrm{Cu}$ and $\mathrm{Pb}$ pollution on the sediments of Dal Lake, whereas no pollution with $\mathrm{Mn}, \mathrm{Ni}$ and Co suggesting the influence of both man-made and natural sources of heavy metal pollution. Being a major tourist destination, most of the lakeshore of Dal Lake is surrounded by developed land such as houses, hotels, restaurants and houseboats and the dominance of clay minerals and fine-grained nature of the sediments may be responsible for its higher heavy metal concentrations [28]. East Dongting Lake in China was reported to have concentrations of $\mathrm{Cd}, \mathrm{Pb}, \mathrm{Cr}$ and $\mathrm{Ni}$ exceeding the geochemical background values where $\mathrm{Cd}$ and $\mathrm{Pb}$ deriving from anthropogenic sources and $\mathrm{Cr}$ and $\mathrm{Ni}$ from natural sources [26]. The high organic carbon from the decomposed lake vegetation could be a sink of heavy metals in the lake sediments [26]. Anchar Lake sediments of Kashmir Valley had low to moderate contamination of $\mathrm{Cu}, \mathrm{Ni}, \mathrm{Zn}$, $\mathrm{Co}$ and $\mathrm{Cr}$ which might be derived from agricultural inputs, domestic effluents and untreated sewage discharges [37].

Loktak Lake, located in the state of Manipur, is the largest shallow natural freshwater lake in northeastern India. It is an important wetland considering its socio-economic, cultural and ecological significance. It is one of the Ramsar sites (designated in 1990) that is listed in the Montreux Record (in 1993) indicating the degrading state of its ecological character. Factors such as hydrosoil texture, characteristics, quantity and quality of input water often influence the distribution of heavy metals in lakes [15]. Large scale industries or power plants are absent in Manipur, but around 36 rivers and rivulets particularly the Nambul River 
that passes through Imphal (capital city) carry a considerable quantity of untreated municipal and domestic wastes into the lake. Land-use land-cover pattern changes in the catchment also resulted in increased input of sediments and nutrients into Loktak Lake [71]. Moreover, the Ithai Barrage, constructed at its major outlet for hydro-electricity, minimizes the outflow of lake water thus, make the water relatively stagnant resulting in further increase of nutrients [41].

Earlier studies on Loktak Lake were confined to its water quality [42,54], floating islands [32], pollen analysis of the sedimentary core [69], macrophytes and phytoplankton community $[44,59]$. However, limited information on heavy metal abundances and pollution status of Loktak sediments are available $[16,45]$. Therefore, we present here the results of our detailed study on the surface sediments of Loktak Lake for heavy metals, major oxides and mineralogy and to assess the heavy metal pollution status of surface sediments. The paper is a first time report on mineralogy and major oxide compositions of the lake sediments that will provide baseline information for further studies for conservation and management of the lake.

\section{Materials and methods}

\subsection{Study area}

Loktak Lake (Fig. 1) of Bishnupur district is located $\sim 48 \mathrm{~km}$ south of Imphal. It has a surface area of $\sim 300 \mathrm{~km}^{2}$ with water depth ranging from 0.5 to $4.6 \mathrm{~m}$. Its location is between $93^{\circ} 46^{\prime}$ and $93^{\circ} 55^{\prime}$ E longitudes and from $24^{\circ}$

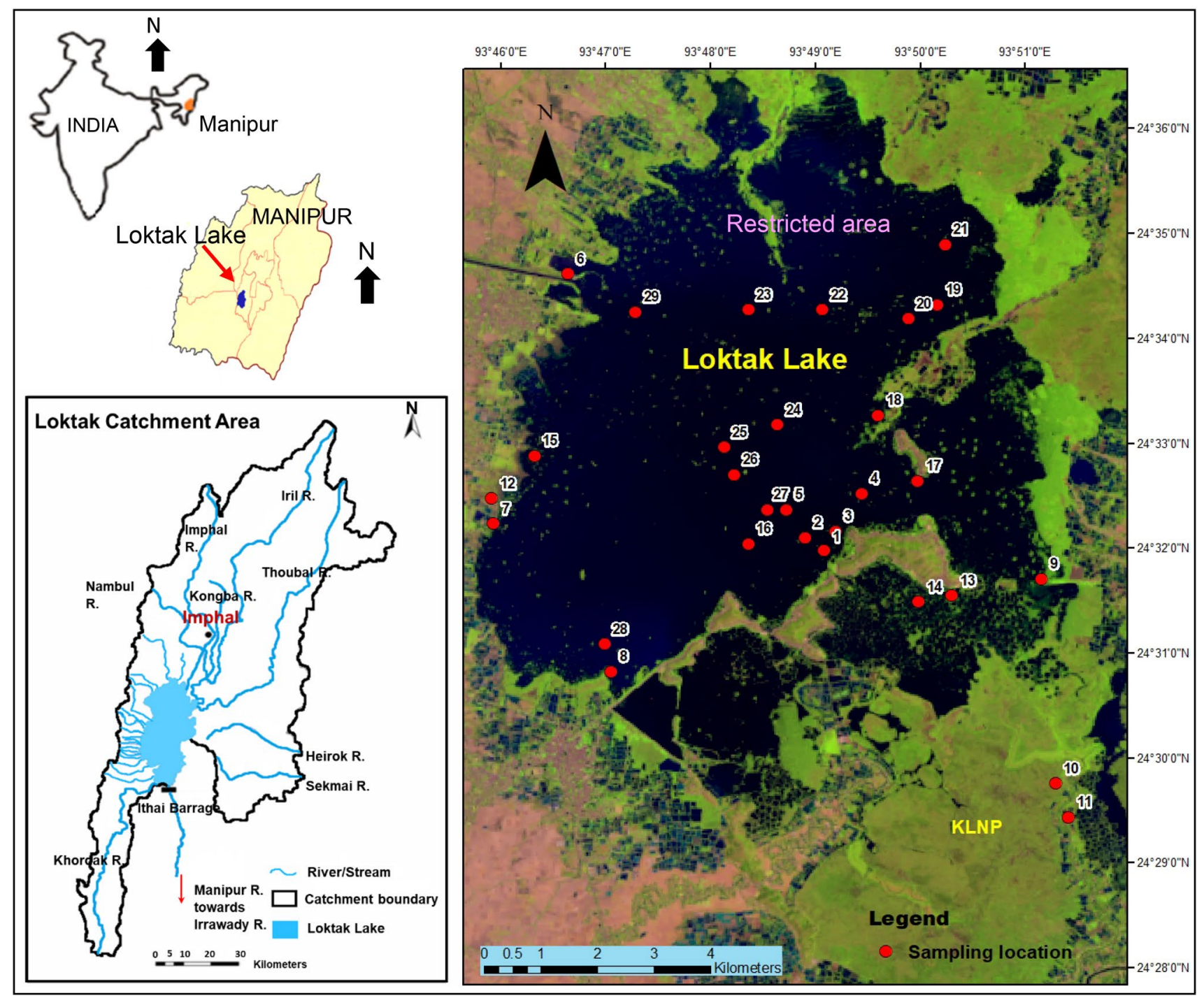

Fig. 1 Map of Loktak Lake showing sampling locations (modified after Singh and Sarkar 2013) 
$25^{\prime}$ to $24^{\circ} 42^{\prime} \mathrm{N}$ latitudes at an altitude of $\sim 760 \mathrm{~m}$ above $\mathrm{msl}$ [71]. The lake is roughly oval-shaped with irregular boundaries prominent on its eastern side. Though its origin is unknown, the tectonic activity might have influenced its formation [63]. Isotopic data on the sediments indicated its existence from the middle of the last glacial period, i.e., $\sim 25,000$ years [46]. The lake receives a huge quantity of floodwater during the monsoon season, thus supplies water for drinking, hydroelectricity and irrigation. The lake serves as a habitat for rich biodiversity including migratory birds. A specific characteristic feature of the lake is the presence of several patches of floating heterogeneous mass of vegetation locally called phumdi. It consists of both live and dead biomass which are held together by a meshwork of rhizomes, crisscrossing roots and stems. It is of variable shapes and sizes, few inches to several feet thick and moves along with the wind. Coincident with the water draw down event during dry season, phumdi stays rooted on the shallower periphery of the lake. Its spread rises and falls during the year consistent with seasonal fluctuations in the lake water level [41]. It provides an important habitat for fish, migratory birds and other lake dwellers including fishermen. It also provides nutrients for the growth of various aquatic flora and fauna, thus helps in maintaining a balanced ecosystem of the lake habitat. The Keibul Lamjao National Park situated on the lake's southeastern part covering an area of $\sim 40 \mathrm{~km}^{2}$ is made up of the continuous mass of phumdi. The national park is a home of several species in addition to Sangai (Rucervus eldii), the deer species endemic to this park.

The direct and indirect catchment area of $\sim 980$ and $7157 \mathrm{~km}^{2}$, respectively, have a semi-tropical climate in the central Manipur/Imphal Valley and semi-temperate to temperate climate in the surrounding hills [61]. The mean annual rainfall of Manipur varies from 1500 to $1700 \mathrm{~mm}$. During summer (May-June), the mean annual temperature is $24^{\circ} \mathrm{C}$, while that of winter (November-January) is $14^{\circ} \mathrm{C}$. The lake receives the maximum amount of water from the western catchment (52\%), followed by direct precipitation (25\%) and other linked channels (23\%) [71]. The oval-shaped Manipur/Imphal Valley slopes gently to the south and the hills align in the north to south trending ridges. The Manipur Hills evolved as an accretionary prism due to the subduction of the Indian plate below the Myanmar plate [66]. The Rock Formations are of TertiaryCretaceous age consists dominantly of marine sediments (clay, silt and sand) of Eocene Disang Formation (minor mudstone, siltstone, sandstone and limestone) along with Oligocene Barail (carbonaceous shales), Miocene Surma (argillaceous sediments) and Tipam Formations (arenaceous sequence) in addition to minor amounts of igneous and metamorphic rocks [62]. Ultramafic igneous rocks of the ophiolitic serpentinites containing small amounts of enstatite, chromite, amphiboles, and magnetite are intruded into the Disang Formation. The central Imphal Valley is covered with $200-300 \mathrm{~m}$ thick alluviums which overlay the Disang shales.

\subsection{Sample collection and chemical analysis}

The surface sediments $(n=29)$ were collected from different sites of the lake during the year 2017. Sampling sites were located using a handheld GPS (Garmin, Model 72H). Surface samples $(0-15 \mathrm{~cm})$ each weighing $\sim 500 \mathrm{~g}$ were grabbed and transferred into clean polybags with zip-lock for laboratory studies (Fig. 1). After air-dried at room temperature, megascopic observation of the samples such as color, texture and calcareousness (with few drops of $1 \mathrm{~N} \mathrm{HCl}$ ) were carried out. About $50 \mathrm{~g}$ of representative samples were powdered to $\sim 200$ mesh size. The soil $\mathrm{pH}$ of representative samples $(n=17)$ was determined in a 1:2 ratio with distilled water. The sediment organic matter (OM) and the carbonate contents were based on loss on ignition (LOI) determined by weight loss measurement using the sequential heating method at 550 and $900^{\circ} \mathrm{C}$, respectively [56].

Based on the color and texture, 6 representative bulk sediment samples (sites 2, 6, 7, 9, 10 and 11) were selected for mineralogical studies by $\mathrm{X}$-ray diffraction (XRD) using $X$ Pert PRO PANalytical diffractometer ( $C u$ as an $x$-ray source with a Ni filter, intensity of $40 \mathrm{~mA}$, voltage of $45 \mathrm{kV}$ ). The range of scan was from $5^{\circ}$ to $60^{\circ} 2 \theta$ and the step size of $0.016^{\circ}$ at a measuring time of one step/sec. Samples at sites 2, 7 and 10 were rerun after treated with ethylene glycol. For this, a film of $1.5 \mathrm{~cm}$ width sample spread on a glass slide was placed in a desiccator with $1-\mathrm{cm}$ height ethylene glycol and kept overnight in an oven at $60^{\circ} \mathrm{C}$. Using $X^{\prime}$ Pert HighScore software, the XRD data were analyzed and $d$-spacing and $2 \theta$ values were used for the identification of minerals using a mineral database [35]. For clay mineralogical studies, 4 representative samples at sites 13 , 21,22 and 28 were selected. $20 \mathrm{~g}$ sample was treated with $100 \mathrm{ml}$ of $25 \%$ acetic acid and kept overnight. The solution was washed with distilled water and then treated with $10 \% \mathrm{H}_{2} \mathrm{O}_{2}$. After 2-3 times of washing, the sample solution was sonicated and transferred to an Atterbergcylinder. The smear of clay fraction collected on a glass slide was run through XRD at diffraction peaks between $3^{\circ}$ and $60^{\circ} 2 \theta$. The samples were rerun after treated with ethylene glycol [67].

To study major element chemistry, $8 \mathrm{~g}$ of 17 representative sample powder pellets were prepared by using the hydraulic pellet press at $2500 \mathrm{psi}$. The pellet was exposed to wavelength dispersive $x$-ray fluorescence spectrometer (WD-XRF, S4 PIONEER) to detect ten major oxides $\left(\mathrm{SiO}_{2}\right.$, $\mathrm{Al}_{2} \mathrm{O}_{3}, \mathrm{FeO} \mathrm{K}_{2} \mathrm{O}, \mathrm{MgO}, \mathrm{TiO}_{2}, \mathrm{CaO}, \mathrm{Na}_{2} \mathrm{O}, \mathrm{P}_{2} \mathrm{O}_{5}$ and $\mathrm{MnO}$ ). The 
accuracy was determined using certified reference materials such as PC3, Omnion monitor and GSP-2.

Heavy metal abundances in the surface sediments $(n=29)$ were determined by the open digestion technique following the B-solution procedure of the Shapiro and Brannock [58] method with some modifications. For this, a $0.5 \mathrm{~g}$ sample was taken in a Teflon crucible, treated with concentrated $10 \mathrm{ml} \mathrm{HF}, 5 \mathrm{ml} \mathrm{HNO}_{3}$ and $3 \mathrm{ml} \mathrm{HClO}_{4}$ and heated on a hot plate. In the second stage, $5 \mathrm{ml} \mathrm{HF}, 10 \mathrm{ml}$ $\mathrm{HNO}_{3}$ and $5 \mathrm{ml} \mathrm{HClO}_{4}$ were added. Finally, $5 \mathrm{ml} \mathrm{HNO}_{3}$ was added. An additional $5 \mathrm{ml} \mathrm{HClO}_{4}$ was added in samples of high organic content for complete digestion. A freshly prepared $25 \mathrm{ml} 1 \mathrm{~N} \mathrm{HCl}$ was added and heated till the sample got into the solution. The solution was made up to $100 \mathrm{ml}$ with distilled water and later analyzed by atomic absorption spectrophotometer (ThermoScientific, M series). Reference materials such as JLK-1, JSD1 and JSD2 (Geological Survey of Japan) were used to check the accuracy of the analysis. A procedural blank was prepared with each batch of digestion. Respective standard solutions for each metal, duplicate samples, procedural blanks and distilled water were rerun after every seven to ten samples to maintain accuracy.

\subsection{Assessment of catchment area weathering}

The chemical index of alteration (CIA) was defined by Nesbitt and Young [50]. It was calculated to evaluate the degree of weathering intensity in the catchment area of Loktak Lake. CIA was calculated using the following Eq. (1):

$\mathrm{ClA}=\left[\mathrm{Al}_{2} \mathrm{O}_{3} /\left(\mathrm{Al}_{2} \mathrm{O}_{3}+\mathrm{CaO}+\mathrm{Na}_{2} \mathrm{O}+\mathrm{K}_{2} \mathrm{O}\right)\right] \times 100$

For calculation of the $\mathrm{CIA}$, the weight percent of major oxides is converted into molecular proportions by dividing the weight percent by their respective molecular weights.

\subsection{Assessment of heavy metal contamination}

To determine the degree of sediment pollution, pollution indices such as enrichment factor (EF), geo-accumulation index $\left(I_{\text {geo }}\right)$ and modified degree of contamination $\left(\mathrm{mC}_{\mathrm{d}}\right)$ were calculated. In this study, average UCC (upper continental crust) values of respective metals were taken as the geochemical background to calculate the pollution indices $[43,68]$.

\subsubsection{Enrichment factor (EF)}

The enrichment factor is used as an index to assess the level of contamination in sediments. To calculate EF, the metals are geochemically normalized to a conservative element such as $\mathrm{Al}, \mathrm{Fe}$ or $\mathrm{Si}$. Fe is commonly employed to normalize metal contaminants $[5,7,72]$. Since Fe is relatively abundant in the study area and its abundance is generally influenced by natural sources, it was used as a reference element. The EF was calculated according to the following Eq. (2):

$\mathrm{EF}=(\mathrm{M} / \mathrm{Fe})_{\text {sample }} /(\mathrm{M} / \mathrm{Fe})_{\text {background }}$

where $(\mathrm{M} / \mathrm{Fe})$ sample is the ratio of concentrations of metal and Fe of a sample, and (M/Fe)background is the ratio of concentrations of the metal and Fe of the background reference.

\subsubsection{Geo-accumulation index $\left(I_{\text {geo }}\right)$}

The geo-accumulation index is a quantification of metal accumulation in sediments [47]. It was calculated using the following Eq. (3):

$I_{\text {geo }}=\log _{2}\left[C_{n} / 1.5 B_{n}\right]$

where $C_{n}$ is the heavy metal concentration in $\mathrm{mg} / \mathrm{kg}, 1.5$ is the background matrix correction factor to minimize the effect of natural lithogenic variations/changes, and $B_{n}$ is the geochemical background value.

\subsubsection{Modified degree of contamination $\left(\mathrm{mC}_{\mathrm{d}}\right)$}

Hakanson first developed the method for calculation of the degree of contamination $\left(C_{d}\right)$ as the sum of contamination factors, $C_{f}^{i}[25]$. The method was based on seven heavy metals ( $\mathrm{Hg}, \mathrm{Cd}, \mathrm{As}, \mathrm{Pb}, \mathrm{Cu}, \mathrm{Cr}$ and $\mathrm{Zn}$ ) and one organic pollutant, $\mathrm{PCB}$, for a given lake. The formula and terminologies for contamination categories were also restricted to these pollutants. The method was later modified into a generalized formula as the sum of contamination factors of the metals analyzed divided by the number of metals, $n$ [1]. The $m C_{d}$ was calculated according to the following Eq. (4):

$m C_{\mathrm{d}}=\sum C_{f}^{i} / n$

where $C_{f}^{i}$ is the ratio between the measured concentration of heavy metal in a sample and the respective geochemical background value, $C_{f}^{i}=C_{\text {surface }}^{i} / C_{\text {reference }}^{i}$.

\subsection{Sediment quality guidelines (SQGs)}

High metal contents in aquatic sediments may cause adverse effects on biological components though the criteria for water quality are not exceeded [51]. If Loktak sediments are polluted with heavy metals, those metals may get into the water and reach the biota. Depending on the frequency of consumption of contaminated biota, metal toxicity may occur to nearby dwellers through the 
food chain. Heavy metal concentrations in sediments are compared with that of SQGs of freshwater ecosystems to evaluate the sediment quality and the risk of heavy metal pollution on the sediment-dwelling organisms [39]. Two categories of the SQGs, i.e., effect range-low (ERL) and effect range-median (ERM) are widely used tools to determine sediment quality. They give baseline information about metal toxicity to aquatic ecosystems.

Mean-ERM-quotient (M-ERM-Q) is used to locate regions of potential hazard concerning sediment quality $[27,52,70]$. M-ERM-Q was calculated for heavy metals such as $\mathrm{Zn}, \mathrm{Cu}, \mathrm{Pb}, \mathrm{Ni}$ and $\mathrm{Cr}$ by following the Eq. (5) given below [38]:

$\mathrm{M}-\mathrm{ERM}-\mathrm{Q}=\left(\sum_{i}^{n} C_{i} / \mathrm{ERM}_{i}\right) / n$

where $C_{i}, \mathrm{ERM}_{i}$ and $n$ are the measured concentration of a metal in a sediment sample, ERM value of metal $i$ and the number of metals, respectively.

\section{Results and discussion}

\subsection{Salient characteristics of Loktak Lake sediments}

The sediments of Loktak Lake show variable colors, i.e., medium to dark brown and light to dark gray. They are clayey to fine silty and the upper half a meter thick sediments in the lake are relatively unconsolidated. The majority of samples has a soapy feeling when dry. Since macrophytes are abundant in the lake, traces of plant materials were observed in the majority of samples. The dried sediments have oxidized patches or tinges. They are non-calcareous as they do not show effervescence with dilute $\mathrm{HCl}$. They are acidic $(\mathrm{pH}=3.9-5.6)$. The acidic nature of Loktak sediments $(\mathrm{pH}=5.3)$ was reported earlier [40]. The organic matter content varies from 7.1 to $32.7 \mathrm{wt} \%$ with a mean of $20.21 \pm 8.49 \mathrm{wt} \%$. The majority of samples from the western periphery of the lake has relatively lower organic matter contents compared to the middle and the eastern periphery which may be due to relatively less prevalence of natural phumdi on the western side of the lake. The acidic $\mathrm{pH}$ and the high organic matter of sediments might result from the decomposition of abundant macrophytes particularly phumdi and their deposition on surface sediments. The soils in the Loktak catchment area are also characterized by low $\mathrm{pH}$, organic carbon rich and high clay content [55]. Organic matter contents of Anchar Lake sediments are controlled by the type of bedrock geology in the catchment, climate, lake flora and fauna and anthropogenic influences along the catchments [37]. The acidic $\mathrm{pH}$ and the rich organic matter content of
Loktak sediments are comparable with that of Lake Chini of Malaysia. Sediments of Lake Chini had $\mathrm{pH}$ ranging from 4.8 to 5.5 and organic matter from 13 to $34.2 \%$ [14].

\subsection{Mineralogy}

The XRD spectra of bulk representative air-dried and glycolated sediments are given in Fig. 2. The samples consist dominantly of quartz $(\sim 4.23,3.33,2.45,2.28,1.98$ and $1.81 \AA)$, followed by smectite $(\sim 15,4.45$ and $2.56 \AA)$, chlorite $(\sim 7.02$ and $3.51 \AA)$, kaolinite $(\sim 7.02$ and $3.51 \AA)$, feldspar (3.18 $\AA$ ), mica ( 2.45 and $1.98 \AA$ ) and hematite $(1.67 \AA)$. After glycolation treatment, the peak of $\sim 15 \AA$ smectite became sharper and the peaks of $\sim 9.90 \AA$ illite disappeared. The minerals observed in the study are consistent with the geology of the catchment area. The XRD spectra of representative air-dried and glycolated clay fractions are given in Fig. 3. The clay fractions consist dominantly of chlorite $(\sim 14.35,7.13,4.73$ and $3.55 \AA)$ and illite $(\sim 10.18,5.05,3.34$ and $2.85 \AA$ A $)$, followed by kaolinite $(\sim 3.56$ and $7.15 \AA ̊ \AA)$, smectite $(\sim 5.00 \AA)$ and mica $(\sim 4.99 \AA)$. Illite $(\sim 10.18 \AA ̊)$ peak reduced after glycolation.

\subsection{Geochemistry}

The major oxide compositions of 17 representative samples are given in Table 1. Supplementary data (Table S1) are also provided. The sediments consist dominantly of (in wt\%) $\mathrm{SiO}_{2}$ (37.74-59.74, mean $\left.=47.92 \pm 6.87\right), \mathrm{Al}_{2} \mathrm{O}_{3}$ $(14.84-20.8$, mean $=18.08 \pm 1.60)$ and $\mathrm{FeO}(6.15-11.17$, mean $=8.38 \pm 1.54)$ with low concentrations of $\mathrm{K}_{2} \mathrm{O}$ $\left(2.55 \pm 0.34\right.$ wt\%), $\mathrm{Na}_{2} \mathrm{O}(0.58 \pm 0.18$ wt\% $)$ and $\mathrm{CaO}$ $(0.25 \pm 0.14 w t \%)$. The $\mathrm{FeO}$ variability in the lake sediments may be due to the dilution effect of organic matter. LOI varies from 8.5 to $33.2 \mathrm{wt} \%$ (Table 1). The table also presents the comparison of concentrations of major oxides with that of UCC, post-Archean average shale (PAAS) and North American shale composite (NASC). Average MnO content is slightly higher than that of NASC, but lower than that of UCC and PAAS. $\mathrm{Al}_{2} \mathrm{O}_{3}$ and $\mathrm{TiO}_{2}$ contents are higher than those of UCC and NASC, but slightly lower than that of PAAS. Compared with respective references, the concentrations of $\mathrm{SiO}_{2}$ are relatively lower and that of $\mathrm{FeO}$ are relatively higher. High FeO contents in the sediments may be a source of $\mathrm{Fe}$ in the water and may affect the existing biota. The relatively higher concentrations of $\mathrm{FeO}$ and $\mathrm{Al}_{2} \mathrm{O}_{3}$ and lower content of $\mathrm{SiO}_{2}$ indicate that the texture of lake sediments is skewed toward clay. The result is consistent with the observed clay nature of sediments. Compared with respective UCC and PAAS values, low concentrations of $\mathrm{SiO}_{2}, \mathrm{MnO}, \mathrm{CaO}, \mathrm{MgO}, \mathrm{Na}_{2} \mathrm{O}, \mathrm{K}_{2} \mathrm{O}$ and $\mathrm{P}_{2} \mathrm{O}_{5}$ and high concentrations of $\mathrm{TiO}_{2}, \mathrm{FeO}$ and $\mathrm{Al}_{2} \mathrm{O}_{3}$ in 
Fig. 2 Representative XRD patterns of air-dried and glycolated surface sediments. Identified peaks are $\mathrm{Sm}=$ Smectite, $\mathrm{I}=$ Illite, $\mathrm{F}=$ Feldspar, $\mathrm{Cl}=$ Chlorite, $\mathrm{K}=$ Kaolinite, $\mathrm{Q}=\mathrm{Quartz}$, $\mathrm{M}=$ Mica, $\mathrm{Hm}=$ Hematite
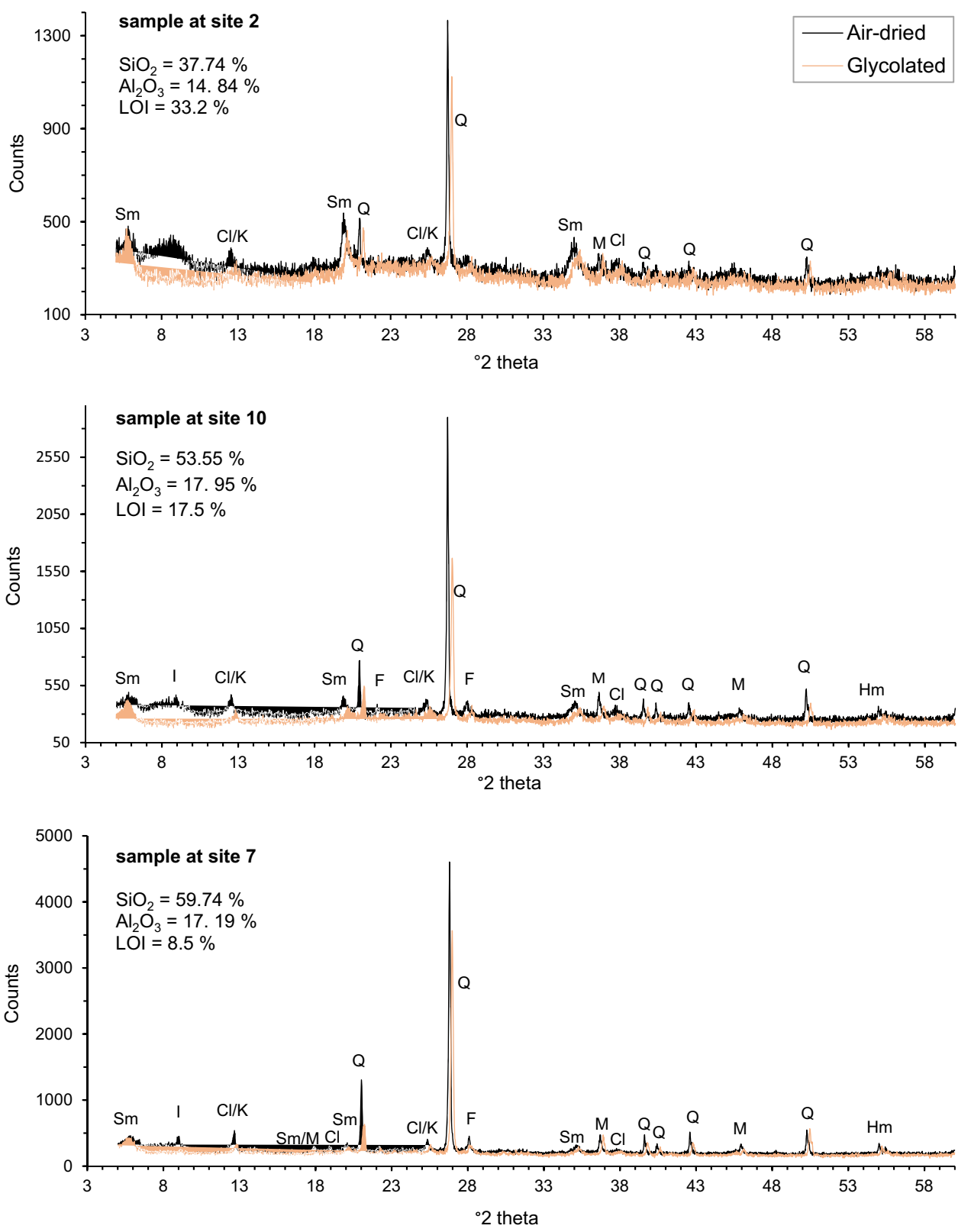

lake surface sediments indicate a terrigenous influx of different source of sediment detritus and strong chemical weathering of the source rocks [49]. The Loktak sediments have lower contents of $\mathrm{K}_{2} \mathrm{O}, \mathrm{MgO}, \mathrm{CaO}$ and $\mathrm{Na}_{2} \mathrm{O}$ than corresponding UCC, PAAS and NASC. $\mathrm{Ca}, \mathrm{Na}, \mathrm{K}$ and $\mathrm{Mg}$ are mobile elements and their relatively lower concentrations indicate the high intensity of weathering of the sediments. The relatively higher $\mathrm{FeO}$ and lower $\mathrm{SiO}_{2}$ contents in sediments suggest the involvement of mafic rock sources. $\mathrm{P}_{2} \mathrm{O}_{5}$ content is lower than that of UCC, slightly higher than that of NASC but similar to that of PAAS. The increased sewage input from Imphal city and chemical fertilizers from the surrounding agricultural area might be the main external sources of phosphorus in the lake $[13,42]$.

\subsection{Assessment of catchment area weathering}

The calculated chemical index of alteration (CIA) of the 17 representative samples from Loktak Lake is given in Table 1 (Detailed data are given in the supplementary Table S1). $\mathrm{CIA}$ values of the average upper crust are 47 , while that of intense weathering is 100 . CIA value below 60 means low chemical weathering, between the range of 60 and 80 indicates moderate and above 80 suggests extreme chemical weathering. The calculated $\mathrm{CIA}$ indicates that 3 
Fig. 3 XRD spectra of representative air-dried and glycolated clay fractions. Identified peaks are $\mathrm{Sm}=$ Smectite, $\mathrm{I}=$ Illite, $\mathrm{Cl}=$ Chlorite, $\mathrm{M}=$ Mica and $\mathrm{K}=$ Kaolinite
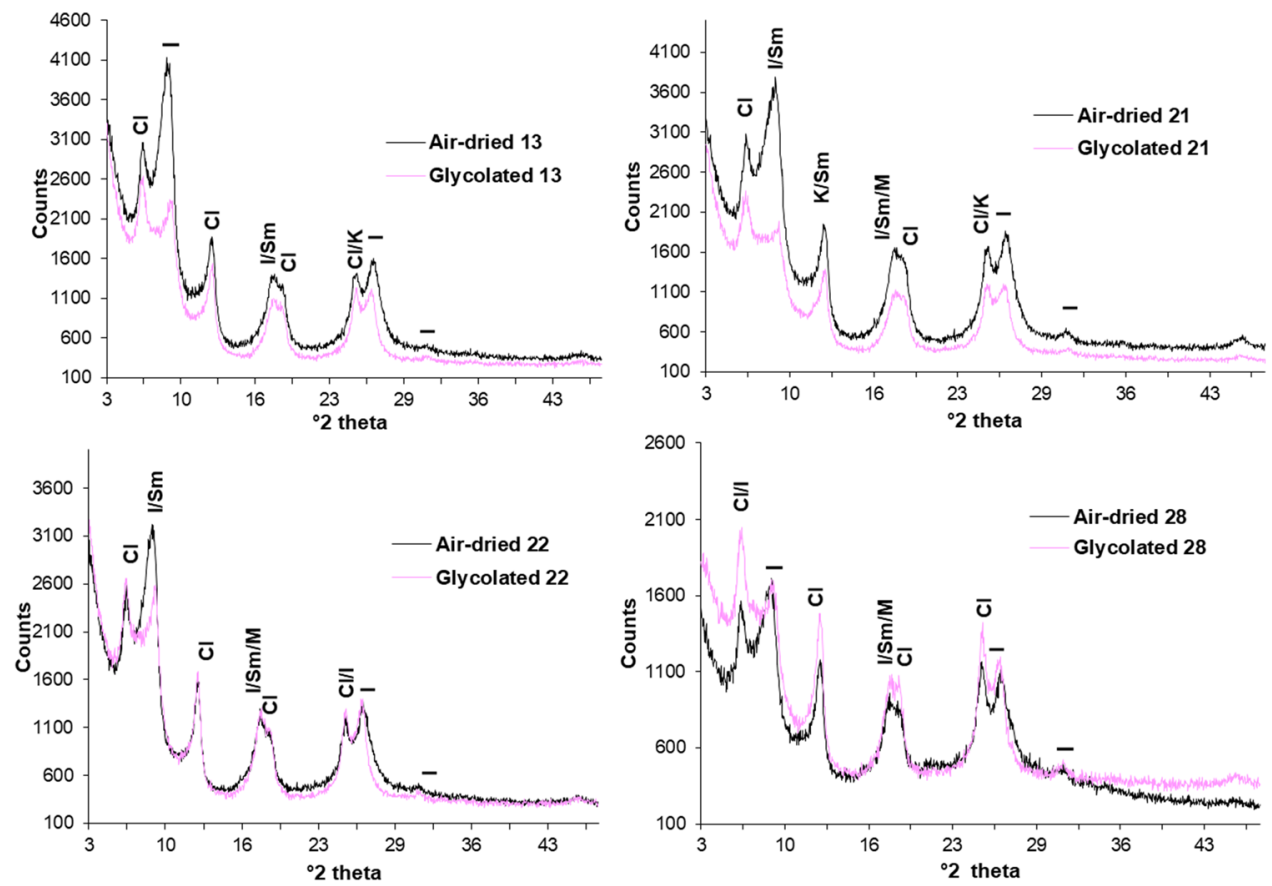

Table 1 Major oxide compositions ( $n=17$, in wt\%) of Loktak Lake sediments in comparison to sediments from references, calculated LOI and $\mathrm{CIA}$

\begin{tabular}{|c|c|c|c|c|c|}
\hline \multirow[t]{2}{*}{ Major oxides } & \multicolumn{2}{|l|}{ Present study } & \multirow[t]{2}{*}{$\mathrm{UCC}^{\mathrm{a}}$} & \multirow[t]{2}{*}{ PAAS $^{\mathrm{a}}$} & \multirow[t]{2}{*}{ NASC $^{b}$} \\
\hline & Range & Mean \pm SD & & & \\
\hline $\mathrm{SiO}_{2}$ & $37.74-59.74$ & $47.92 \pm 6.87$ & 66.0 & 62.80 & 64.80 \\
\hline $\mathrm{Al}_{2} \mathrm{O}_{3}$ & $14.84-20.8$ & $18.08 \pm 1.60$ & 15.2 & 18.90 & 16.90 \\
\hline $\mathrm{FeO}$ & $6.15-11.17$ & $8.38 \pm 1.54$ & 4.5 & 5.85 & 5.66 \\
\hline $\mathrm{K}_{2} \mathrm{O}$ & $2.01-3.24$ & $2.55 \pm 0.34$ & 3.4 & 3.70 & 3.97 \\
\hline $\mathrm{MgO}$ & $1.28-2.46$ & $1.94 \pm 0.30$ & 2.2 & 2.20 & 2.86 \\
\hline $\mathrm{TiO}_{2}$ & $0.70-1.11$ & $0.93 \pm 0.13$ & 0.5 & 1.00 & 0.70 \\
\hline $\mathrm{CaO}$ & $0.08-0.65$ & $0.25 \pm 0.14$ & 4.2 & 1.30 & 3.63 \\
\hline $\mathrm{Na}_{2} \mathrm{O}$ & $0.3-0.9$ & $0.58 \pm 0.18$ & 3.9 & 1.20 & 1.14 \\
\hline $\mathrm{P}_{2} \mathrm{O}_{5}$ & $0.08-0.27$ & $0.16 \pm 0.06$ & 0.4 & 0.16 & 0.13 \\
\hline $\mathrm{MnO}$ & $0.05-0.13$ & $0.07 \pm 0.02$ & 0.1 & 0.11 & 0.06 \\
\hline LOI & $8.5-33.2$ & $20.37 \pm 7.04$ & - & - & - \\
\hline Total & $97.23-105.64$ & $101.24 \pm 2.51$ & - & - & - \\
\hline $\mathrm{CIA}$ & $76.86-84.98$ & $81.37 \pm 1.92$ & - & - & - \\
\hline
\end{tabular}

${ }^{\mathrm{a}}$ Taylor and McLennan [68]; a McLennan [43]; ${ }^{\mathrm{b}}$ Gromet et al. [20]

samples (at sites 2, 10 and 29) have values ranging from 76.86 to 79.69 that show moderate chemical weathering. The rest 14 samples with $\mathrm{CIA}$ values ranging from 80.59 to 84.98 show extreme chemical weathering. The overall CIA values in the present study ranging from 76.86 to 84.98 with a mean of $81.37 \pm 1.92$ indicate moderate to extreme chemical weathering of lithologies of the catchment area. The CIA values are in a narrow range whose values are close to 80 . The clayey and fine silty nature of sediments also reveal the advanced stage of the catchment weathering. Since the past few years, Loktak Lake catchment is being eroded bringing a huge quantity of sediments into the lake due to shifting cultivation and deforestation in the higher altitude. Annually more than 650,000 metric tons of sediments are brought into Loktak from its catchment [71]. The frequent flood events in the central valley during the monsoon season might accelerate the weathering process. High CIA values (87-95) were also reported in Dal Lake reflecting extreme weathering [28] and CIA value of 71 in Nainital Lake sediments [8] and that ranging from 75.2 to 78.1 in Rewalsar Lake sediments [10] suggest moderate chemical weathering in their catchment areas.

Correlation coefficients are used to determine the relationships among major oxides. The Pearson's correlation coefficients $(r)$ among the major oxides, total LOI and CIA are given in Table 2 . $\mathrm{SiO}_{2}$ has a very strong $(r>0.8)$ positive correlation with $\mathrm{Na}_{2} \mathrm{O}(r=0.919 ; p>0.01)$, negative correlation with LOI $(r=-0.906 ; p>0.01)$, strong $(r=0.7-0.8)$ positive correlation with $\mathrm{TiO}_{2}(r=0.774 ; p>0.01)$, moderate $(r=0.5-0.6)$ positive correlation with $\mathrm{MgO}(r=0.532$; $p=0.05)$, negative correlations with $\mathrm{K}_{2} \mathrm{O}(r=-0.747$; $p>0.01)$ and $\mathrm{FeO}(r=-0.631 ; p>0.05)$, respectively, and low positive correlation with $\mathrm{Al}_{2} \mathrm{O}_{3} . \mathrm{Al}_{2} \mathrm{O}_{3}$ has a very strong positive correlation with $\mathrm{ClA}(r=0.886 ; p>0.01)$ and good ( $r=0.6-0.7)$ positive correlation with $\mathrm{TiO}_{2}(r=0.648$; $p>0.01$ ). The high $\mathrm{Al}_{2} \mathrm{O}_{3}$ content and high $\mathrm{ClA}$ value and their strong positive correlation corroborates the geology of the catchment area. $\mathrm{FeO}$ has moderate positive correlation with $\mathrm{MnO}$ and $\mathrm{K}_{2} \mathrm{O}(r=0.571$ and $r=533 ; p>0.05$, respectively) and $\mathrm{MnO}$ has a strong positive correlation 
Table 2 Correlations among major oxides, LOI and CIA of surface sediments of Loktak Lake

\begin{tabular}{|c|c|c|c|c|c|c|c|c|c|c|c|c|}
\hline & $\mathrm{SiO}_{2}$ & $\mathrm{Al}_{2} \mathrm{O}_{3}$ & $\mathrm{FeO}$ & $\mathrm{K}_{2} \mathrm{O}$ & $\mathrm{MgO}$ & $\mathrm{TiO}_{2}$ & $\mathrm{CaO}$ & $\mathrm{Na}_{2} \mathrm{O}$ & $\mathrm{P}_{2} \mathrm{O}_{5}$ & $\mathrm{MnO}$ & LOI & $\mathrm{CIA}$ \\
\hline $\mathrm{SiO}_{2}$ & 1 & & & & & & & & & & & \\
\hline $\mathrm{Al}_{2} \mathrm{O}_{3}$ & .344 & 1 & & & & & & & & & & \\
\hline $\mathrm{FeO}$ & $-.631^{* *}$ & -.246 & 1 & & & & & & & & & \\
\hline $\mathrm{K}_{2} \mathrm{O}$ & $-.747^{* *}$ & .122 & $.533^{*}$ & 1 & & & & & & & & \\
\hline $\mathrm{MgO}$ & $.532^{*}$ & .405 & -.197 & -.149 & 1 & & & & & & & \\
\hline $\mathrm{TiO}_{2}$ & $.774^{* *}$ & $.648^{* *}$ & -.352 & -.304 & $.640^{* *}$ & 1 & & & & & & \\
\hline $\mathrm{CaO}$ & -.296 & $-.521^{*}$ & .008 & -.192 & -.349 & $-.512^{*}$ & 1 & & & & & \\
\hline $\mathrm{Na}_{2} \mathrm{O}$ & $.919^{* *}$ & .302 & -.455 & $-.530^{*}$ & $.649^{* * *}$ & $.808^{* *}$ & -.423 & 1 & & & & \\
\hline $\mathrm{P}_{2} \mathrm{O}_{5}$ & -.097 & -.433 & .341 & -.025 & -.086 & -.194 & .436 & .057 & 1 & & & \\
\hline $\mathrm{MnO}$ & -.309 & $-.564^{*}$ & $.571 *$ & .017 & -.132 & -.433 & .470 & -.238 & $.713^{* *}$ & 1 & & \\
\hline LOI & $-.906^{* *}$ & $-.509^{*}$ & .480 & $.504^{*}$ & $-.552^{*}$ & $-.910^{* *}$ & $.566^{*}$ & $-.881^{* *}$ & .274 & .468 & 1 & \\
\hline $\mathrm{CIA}$ & .384 & $.886^{* *}$ & -.269 & -.040 & .230 & $.586^{*}$ & $-.640^{* *}$ & .282 & $-.592^{*}$ & $-.585^{*}$ & $-.543^{*}$ & 1 \\
\hline
\end{tabular}

${ }^{*}$ Correlation is significant at the 0.05 level (2-tailed)

${ }^{* *}$ Correlation is significant at the 0.01 level (2-tailed)

with $\mathrm{P}_{2} \mathrm{O}_{5}(r=0.713 ; p>0.01)$. $\mathrm{TiO}_{2}$ has a strong positive correlation with $\mathrm{Na}_{2} \mathrm{O}(r=0.808 ; p>0.01)$, moderate positive correlation with $\mathrm{CIA}(r=0.586 ; p>0.05)$. LOI has moderate correlation only with $\mathrm{CaO}(r=0.566 ; p>0.05)$ and very strong negative correlations with $\mathrm{TiO}_{2}(r=-0.910 ; p>0.01)$, $\mathrm{SiO}_{2}(r=-0.906 ; p>0.01)$ and $\mathrm{Na}_{2} \mathrm{O}(r=-0.881 ; p>0.01)$.

\subsection{Heavy metal abundances}

Heavy metal concentrations in sediments of Loktak Lake are presented in Table 3. The detailed data are presented in supplementary Table S2. The average concentrations of heavy metals are (in $\mathrm{mg} / \mathrm{kg}$ ) $\mathrm{Zn}=117 \pm 23.45$, $\mathrm{Cu}=67 \pm 12.87, \mathrm{~Pb}=17 \pm 7.47, \mathrm{Ni}=194 \pm 30.12$, $\mathrm{Mn}=425 \pm 168.99, \mathrm{Cr}=282 \pm 45.25, \mathrm{Co}=34 \pm 13.67$ and $\mathrm{Fe}=7 \pm 1.38 \mathrm{wt} \%$ and they follow an order of $\mathrm{Fe}>\mathrm{Mn}>\mathrm{Cr}$ $>\mathrm{Ni}>\mathrm{Zn}>\mathrm{Cu}>\mathrm{Co}>\mathrm{Pb}$. The relative enrichment or depletion of metals in sediments infers changes in the source in response to weathering, sedimentation and anthropogenic inputs [37]. Different factors lead to variations in the distribution and concentration of metals in sediments such as clay content, soil pH, organic matter, cation exchange capacity, iron and manganese oxides, etc. [17]. Fe concentration is generally high in lake sediments since it is one of the major elements in Earth's crust. Its higher concentrations in Loktak sediments indicate the ultramafic nature of the parent rocks. Similarly, Mn content is also relatively high. $\mathrm{Mn}$ is naturally found associated with Fe. The sample at site 28 near the Moirang River inlet has relatively higher concentrations of the majority of metals since the river passes through several agricultural fields and the Moirang market just before joining the lake. Since Loktak Lake is the ending of many rivers, it acts as a sink of pollutants carried by the rivers. Solid wastes of more than 77.13 million tons and sewage of $33,148 \mathrm{~m}^{3}$ are generated daily by a population of about 0.28 million living in the
Table 3 Statistics of heavy metal concentrations $(n=29$, in $\mathrm{mg} / \mathrm{L}, \mathrm{OM}$ and $\mathrm{Fe}$ in wt\%) of Loktak sediments and their comparison with other sediments from references and SQGs

\begin{tabular}{|c|c|c|c|c|c|c|c|}
\hline \multirow[t]{2}{*}{ Elements } & \multicolumn{2}{|c|}{ Present study } & \multirow[t]{2}{*}{$\mathrm{UCC}^{\mathrm{a}}$} & \multirow[t]{2}{*}{ PAAS $^{\mathrm{a}}$} & \multirow[t]{2}{*}{ NASC $^{b}$} & \multirow[t]{2}{*}{$\mathrm{ERL}^{\mathrm{c}}$} & \multirow[t]{2}{*}{ ERM $^{d}$} \\
\hline & Range & Mean \pm SD & & & & & \\
\hline $\mathrm{Zn}$ & $94-218$ & $117 \pm 23.45$ & 71 & 85 & - & 120 & 270 \\
\hline $\mathrm{Cu}$ & $47-94$ & $67 \pm 12.87$ & 25 & 50 & - & 70 & 390 \\
\hline $\mathrm{Pb}$ & $8-41$ & $17 \pm 7.47$ & 17 & 20 & 20 & 35 & 110 \\
\hline $\mathrm{Ni}$ & $140-274$ & $194 \pm 30.12$ & 44 & 55.00 & 58.00 & 30 & 50 \\
\hline $\mathrm{Mn}$ & 208-895 & $425 \pm 168.99$ & 600 & - & - & - & - \\
\hline $\mathrm{Cr}$ & $211-418$ & $282 \pm 45.25$ & 83 & 110.00 & 125.00 & 80 & 145 \\
\hline Co & $12-87$ & $34 \pm 13.67$ & 17 & 23.0 & 25.7 & - & - \\
\hline $\mathrm{Fe}$ & $4.53-9.82$ & $6.55 \pm 1.38$ & 3.5 & - & - & - & - \\
\hline $\mathrm{OM}^{\mathrm{e}}$ & $7.1-32.7$ & $20.2 \pm 8.49$ & & & & & \\
\hline
\end{tabular}

${ }^{\mathrm{a}}$ Taylor and McLennan [68]; ${ }^{\mathrm{a}}$ McLennan [43]; ${ }^{\mathrm{b}}$ Gromet et al. [20]; ${ }^{\mathrm{c}}$ Effect range-low and ${ }^{\mathrm{d}}$ Effect range median for freshwater ecosystem [39], ${ }^{\text {eOrganic matter }}$ 
catchment of the Nambul River [71]. Enhanced unsustainable agricultural activities such as shifting cultivation in the Loktak catchment area particularly in the hills, lead to land degradation resulting in increased soil erosion and lake sedimentation [24]. The lake area contributes $14 \%$ of the total state population and constitutes about $6.8 \%$ of the total land use pattern in Manipur [31]. Imphal, the capital city alone occupies $71 \%$ of the urban population of the catchment [24]. Several fish farms in the lake periphery also might have added pollutants. Moreover, direct input of untreated wastes, agricultural run-offs, and settlements in and around the lake adds pollution to the lake [65].

The average concentrations of heavy metal in Loktak sediments were compared with that of UCC, PAAS and NASC as given in Table 3. The average concentrations of heavy metals (except $\mathrm{Mn}$ ) are higher than those in UCC, PAAS and NASC $[20,43,68]$. Cr concentrations are about 2-4 times higher than that of UCC. Cr tends to get distributed in mafic igneous rocks and are concentrated in various types of intrusions and deposits [29]. Peat exhibits a high sorption capacity for $\mathrm{Cr}$ that binds the metal mainly as an insoluble metal-organic complex [29]. Ni contents are about 3-6 times higher than that of UCC. Naturally, higher Ni concentrations are observed in sediments derived from serpentine rocks [30]. The relatively higher concentrations of $\mathrm{Cr}$ and $\mathrm{Ni}$ in Loktak sediments correspond with the geology of the catchment area. Abnormally rich $\mathrm{Ni}$ and $\mathrm{Cr}$ contents in Yercaud Lake sediments were considered to be derived from adjoining mafic rock exposures [19]. The majority of samples has $\mathrm{Cu}$ concentrations about 2-4 times higher than that of UCC. The concentration of $\mathrm{Mn}$ in 5 samples (at sites 3, 69, 15 and 25 ) is higher than that of the respective UCC. Mn may be considered to be originated from natural sources since it is one of the abundant elements in the Earth's crust. Pb exists rarely in nature and it can easily come from anthropogenic activities. $\mathrm{Pb}$ is generally an exhaust from motor vehicles and the increased number of cars and trucks in the catchment can be its atmospheric source. Earlier studies have mentioned the atmospheric fall out of $\mathrm{Pb}$ in the environment $[21,23]$. Other sources of $\mathrm{Pb}$ might be inputs from paints, tourists' boats, etc. Its mean concentration is similar to that of UCC, whereas samples of 3 (at sites 6, 18 and 29) have slightly higher and $8(5,12,13,14,15,21,22$ and 28) have relatively higher concentrations. Except for $\mathrm{Mn}$ and $\mathrm{Pb}$, the mean concentrations of $\mathrm{Zn}, \mathrm{Co}, \mathrm{Fe}, \mathrm{Cu}, \mathrm{Cr}$ and $\mathrm{Ni}$ are about 2-4 times that of the respective crustal average. The high concentration of heavy metals might have come from their high clay contents and the high organic matter. Lake Hamahara of Japan had metals enriched in the clays compared to the sands [3]. Khalil et al. [33] reported heavy metal distributions associated with organic matter content in Burullus Lake sediments. The enrichment of heavy metals in soils of Nansi Lake is due to the strong adsorption capacity of clay [22]. Because of the fine nature, clay provides the surface area for the adsorption and attraction of metal ions.

The heavy metal concentrations in Loktak sediments are compared with that of other freshwater lakes elsewhere (Table 4). Loktak Lake has higher concentrations of $\mathrm{Pb}, \mathrm{Ni}$ and $\mathrm{Fe}$, but lower concentrations of $\mathrm{Mn}$ and $\mathrm{Zn}$ than that of Chauli beel, an ox-bow lake along the Barak River in northeastern India. Loktak Lake has higher Ni concentrations than that of Dal Lake, whereas Dal Lake has higher concentrations of $\mathrm{Mn}, \mathrm{Zn}$ and $\mathrm{Cu}$, but with similar $\mathrm{Pb}$ and $\mathrm{Co}$ contents. Compared with Nainital Lake, Loktak Lake has relatively higher concentrations of $\mathrm{Fe}$ and $\mathrm{Ni}$, lower contents of $\mathrm{Zn}$ and $\mathrm{Pb}$, but with similar $\mathrm{Cu}$ and $\mathrm{Co}$ contents. Loktak Lake has higher concentrations of $\mathrm{Ni}$ and $\mathrm{Co}$, lower contents of $\mathrm{Cu}, \mathrm{Pb}$ and $\mathrm{Zn}$ than that of Manchar

Table 4 Comparison of heavy metal abundances (in $\mathrm{mg} / \mathrm{kg}$ ) of Loktak Lake sediments with those of other freshwater lakes of the world

\begin{tabular}{lllllllll}
\hline Lakes & $\mathrm{Zn}$ & $\mathrm{Cu}$ & $\mathrm{Pb}$ & $\mathrm{Ni}$ & $\mathrm{Mn}$ & $\mathrm{Cr}$ & $\mathrm{Co}$ & $\mathrm{Fe}$ \\
\hline Present study & $117 \pm 23.45$ & $67 \pm 12.87$ & $17 \pm 7.47$ & $194 \pm 30.12$ & $425 \pm 168.99$ & $282 \pm 45.25$ & $34 \pm 13.67$ & $65,513.79 \pm 13,763.9$ \\
Chauli Lake, India $^{\mathrm{a}}$ & $332.3-771.86$ & $57.47-160$ & $3.73-7.89$ & $29.9-71.1$ & $1309.5-2690.5$ & $207.8-465.4$ & - & $1485.04-2836.4$ \\
Dal Lake, India $^{\mathrm{b}}$ & $231-309$ & $82-193$ & $18-32$ & $13-22$ & $747-1178$ & - & $12-27$ & - \\
Nainital, India $^{\mathrm{C}}$ & 381 & 88 & 99 & 61 & - & - & 25 & 65 \\
Manchar Lake, Pakistan $^{\mathrm{d}}$ & 667.5 & 376.2 & 323 & 73.7 & 498 & 254 & 14.1 & - \\
Poyang Lake, China $^{\mathrm{e}}$ & 104.17 & 35.17 & 32.63 & 30.47 & - & 91.39 & 12.84 & - \\
Yercaud Lake, India $^{\mathrm{f}}$ & 168.9 & 574 & 30.0 & 146.9 & 372 & 384.8 & 108.4 & 107,395 \\
Vembanad Lake, India $^{\mathrm{g}}$ & 184.5 & 30.9 & 32.6 & 48.7 & 461 & 107.5 & 18.6 & 54,000 \\
Lake Nasser, Egypt $^{\mathrm{h}}$ & 35.4 & 21.8 & 10.9 & 27.6 & 280 & 30.8 & - & 12,418 \\
Anchar Lake, India $^{\mathrm{i}}$ & 130.93 & 68.13 & 26.6 & 54.03 & 734.4 & 81 & 21.66 & 51,601 \\
Rewalsar Lake, India $^{\mathrm{j}}$ & 353 & 42 & 39.4 & 44 & 387 & 75 & - & 19,374 \\
\hline
\end{tabular}

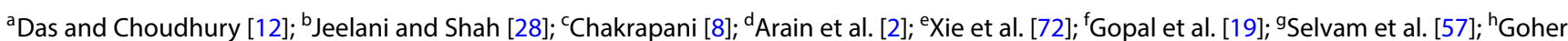
et al. [18]; 'Lone et al. [37]; 'Das and Haake [10] 
Lake, but with similar $\mathrm{Mn}$ and $\mathrm{Cr}$ contents. Loktak Lake has $\mathrm{Ni}$ and $\mathrm{Cr}$ concentrations higher than that of Poyang Lake, whereas $\mathrm{Pb}$ content is relatively lower. It is observed from the above comparisons that the concentrations of $\mathrm{Fe}, \mathrm{Ni}$ and $\mathrm{Cr}$ are relatively higher in Loktak sediments. This may be because of the high rate of weathering processes of the catchment area that are part of the ultramafic rocks of the ophiolitic serpentinites of the eastern Himalayas. However, the higher concentration of $\mathrm{Pb}$ than that of UCC in 11 samples also indicates an increasing anthropogenic influence on the lake [42].

\subsection{Assessment of heavy metal contamination}

Quantification of heavy metal pollution in lake sediments helps to determine the pollution level and maintain the ecological health status of the aquatic environment. The following pollution indices are widely used geochemical approaches to assess heavy metal pollution in sediments.

\subsubsection{Enrichment factor}

Enrichment factor is generally used to evaluate the heavy metal enrichment by anthropogenic activities. The EF values suggested by Chen et al. [9] to interpret the different levels of metal pollution are $E F<1$, no enrichment; $E F=1-3$, minor enrichment; $E F=3-5$, moderate enrichment; $E F=5-10$, moderately severe enrichment; $E F=10-25$, severe enrichment; $E F=25-50$, very severe enrichment; $E F>50$, extremely severe enrichment. When sedimentation occurs due to natural processes, the heavy metal concentrations have a linear relationship with the reference metal [5]. In regions having less anthropogenic influence, EF values close to unity suggest a crustal source, whereas values higher than 1.5 indicate a significant portion of the metals derived from non-crustal or non-natural sources [5]. Statistics of EF of the heavy metals in Loktak sediments are shown in Table 5 (Supplementary data are provided by Table S3). The EF of $\mathrm{Cr}$ ranges from 0.91 to 2.97. There is a minor enrichment of $\mathrm{Cr}$ in almost all the samples except the sample at site 25 from the middle of the lake with EF slightly below 1 showing no enrichment. The EF of Ni ranges from 1.43 to 4.32. The majority of samples has minor enrichment of $\mathrm{Ni}$ and samples at sites 13 ,
18,21 and 28 have moderate enrichment with their EF values slightly above that of minor enrichment. Samples at sites 13 and 18 are close to Thanga and Karang Islands, respectively, and those at 21 and 28 are from the northeastern portion and the Moirang River inlet, respectively. Minor enrichment of $\mathrm{Pb}$ is observed in 3 samples (at sites 12, 21 and 28), whereas no enrichment for the rest of the samples. There is a minor enrichment of $\mathrm{Cu}$ in almost all the samples, $C o$ in 15 and $Z n$ in 10 samples which are slightly above unity, whereas no enrichment of $\mathrm{Mn}$ for all the samples. No enrichment of $\mathrm{Mn}$ also occurred in the sediments of Yercaud Lake [19] and Lake Valencia [4]. With the high-organic matter content of Loktak sediments, $\mathrm{Cu}$ could form $\mathrm{Cu}$-organic matter complexes. The average EF for $\mathrm{Ni} \mathrm{(2.46)}$ is the highest, followed by $\mathrm{Cr}(1.90)$ and $\mathrm{Cu}$ (1.49) (Table 5). The average EF for all the metals ranges from 0.37 to 2.46 and their values follow an order of $\mathrm{Ni}>$ $\mathrm{Cr}>\mathrm{Cu}>\mathrm{Co}>\mathrm{Zn}>\mathrm{Pb}>\mathrm{Mn}$. Hence, the overall EF ranges from no enrichment to moderate enrichment with minor enrichment in the majority of the samples.

\subsubsection{Geo-accumulation index}

Geo-accumulation index values are categorized into 7 classes depending on numeral values of the index, each one representing different levels of pollution. The categories of $l_{\text {geo }}$ are: $<0=$ uncontaminated; $0-1=$ uncontaminated to moderately contaminated; $1-2=$ moderately contaminated; $2-3=$ moderately to strongly contaminated; $3-4=$ strongly contaminated; $4-5=$ strongly to extremely contaminated; $>5=$ extremely contaminated [47]. The boxplot for the $I_{\text {geo }}$ is shown in Fig. 4 (Supplementary data is provided by Table S3). According to the contamination categories, Loktak Lake sediments are moderately contaminated with $\mathrm{Ni}$. Samples of 21 are moderately contaminated with $\mathrm{Cr}$ and the rest are uncontaminated to moderately contaminated. Samples of 10 are moderately contaminated with $\mathrm{Cu}$ (at sites 14 , $15,16,17,18,19,2021,22$ and 23) and the rest are uncontaminated to moderately contaminated category. There is no contamination with $\mathrm{Mn}$ and $\mathrm{Pb}$ except 5 samples (at sites 12, 13, 21, 22 and 28) have $\mathrm{Pb}$ in the uncontaminated to moderately contaminated category. The average $I_{\text {geo }}$ values of $\mathrm{Zn}, \mathrm{Pb}, \mathrm{Mn}, \mathrm{Co}$ and $\mathrm{Fe}$ are

Table $5 \mathrm{EF}$ and $\mathrm{mC}_{\mathrm{d}}$

\begin{tabular}{|c|c|c|c|c|c|c|c|c|}
\hline & \multicolumn{4}{|l|}{$\mathrm{EF}$} & \multirow[b]{2}{*}{$\mathrm{Mn}$} & \multirow[b]{2}{*}{$\mathrm{Cr}$} & \multirow[b]{2}{*}{ Co } & \multirow[t]{2}{*}{$m C_{d}$} \\
\hline & $\mathrm{Zn}$ & $\mathrm{Cu}$ & $\mathrm{Pb}$ & $\mathrm{Ni}$ & & & & \\
\hline Min & 0.52 & 0.85 & 0.23 & 1.43 & 0.19 & 0.91 & 0.50 & 1.82 \\
\hline Max & 1.70 & 2.91 & 1.33 & 4.32 & 0.80 & 2.79 & 2.83 & 3.41 \\
\hline Mean & 0.93 & 1.49 & 0.58 & 2.46 & 0.38 & 1.90 & 1.10 & 2.21 \\
\hline STDEV & 0.29 & 0.44 & 0.30 & 0.63 & 0.15 & 0.49 & 0.51 & 0.28 \\
\hline
\end{tabular}




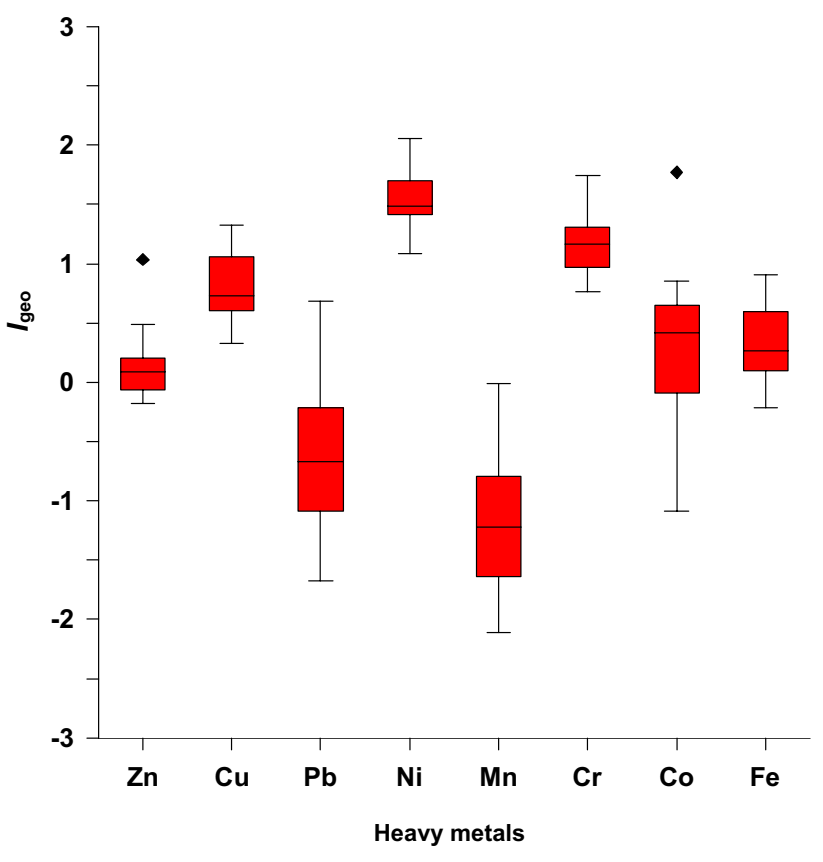

Fig. 4 Box-and-whisker plots for heavy metals and geo-accumulation index $\left(I_{\text {geo }}\right)$ of Loktak sediments

below zero which means that as a whole the heavy metals are non-polluting. The average $I_{\text {geo }}$ value is the highest for $\mathrm{Ni}$ (1.54) which is, followed by $\mathrm{Cr}$ (1.16) and $\mathrm{Cu}$ (0.81). The average $I_{\text {geo }}$ values follow an order of $\mathrm{Ni}>$ $\mathrm{Cr}>\mathrm{Cu}>\mathrm{Co}>\mathrm{Fe}>\mathrm{Zn}>\mathrm{Pb}>\mathrm{Mn}$. The overall $\mathrm{I}_{\text {geo }}$ values for the heavy metals range from non-contamination to moderate contamination. However, the high $I_{\text {geo }}$ values of metals such as $\mathrm{Ni}$ and $\mathrm{Cr}$ are suggestive of the predominance of geogenic origin and no significant anthropogenic accumulation of heavy metals in the lake sediments.

\subsubsection{Modified degree of contamination}

The modified degree of contamination gives an overall contamination degree for a given sample [1]. The pollution status can be verified based on the gradations of contamination such as $\mathrm{mC}_{\mathrm{d}}<1.5=$ nil to very low degree of contamination; $1.5 \leq \mathrm{mC}_{\mathrm{d}}<2=$ low degree of contamination; $2 \leq \mathrm{mC}_{\mathrm{d}}<4=$ moderate degree of contamination; $4 \leq \mathrm{mC}_{\mathrm{d}}<8=$ high degree of contamination; $8 \leq m C_{d}<16=$ very high degree of contamination; $16 \leq \mathrm{mC}_{\mathrm{d}}<32=$ extremely high degree of contamination; $\mathrm{mC}_{\mathrm{d}} \geq 32=$ ultra-high degree of contamination. The statistics of $m C_{d}$ of the Loktak sediments are shown in Table 5 (Supplementary data are provided by Table S3). The overall $\mathrm{mC}_{\mathrm{d}}$ ranges from 1.82 to 3.41 with a mean of $2.21 \pm 0.28$. According to contamination categories, the majority of samples have a moderate degree of contamination with low degree of contamination at sites 7,8 and 27. The assessment of contamination by following the above methods, it is observed that pollution in the Loktak sediments is primarily due to natural sources along with secondary anthropogenic influences.

Correlation analysis is generally used to determine the potential common source of metals [23]. A high correlation suggests a similar source, whereas the low correlation means a more varied source of contamination. The Pearson's correlation analysis among heavy metals and $\mathrm{mC}_{d}$ are given in Table 6. $\mathrm{Zn}$ has strong to moderate positive correlations with $\mathrm{Co}, \mathrm{mC}_{\mathrm{d}}, \mathrm{Cr}$, $\mathrm{Pb}$ and $\mathrm{Ni}(r=0.779, r=0.766$, $r=0.616, r=0.510, p>0.01 ; r=0.406, p>0.05$, respectively), but low negative correlations with organic matter and Fe. Cu has a good correlation with $\mathrm{Ni}(r=0.573 ; p>0.01)$ and moderate negative correlation with $\mathrm{Mn}$. $\mathrm{Pb}$ has good positive correlation with $\mathrm{mC}_{\mathrm{d}}(r=0.627 ; p>0.01)$ and moderate positive correlations with $\mathrm{Ni}$ and $\mathrm{Cr}(r=0.415$, $r=0.444 ; p>0.05$, respectively). There is a good correlation between $\mathrm{Ni}$ and $\mathrm{Cr}(r=0.513 ; p=0.01)$ and both are
Table 6 Correlations among heavy metal concentrations, $\mathrm{OM}$ and $\mathrm{mC}_{\mathrm{d}}$ of sediments of Loktak Lake

\begin{tabular}{lllllllllll}
\hline & $\mathrm{Zn}$ & $\mathrm{Cu}$ & $\mathrm{Pb}$ & $\mathrm{Ni}$ & $\mathrm{Mn}$ & $\mathrm{Cr}$ & $\mathrm{Co}$ & $\mathrm{Fe}$ & $\mathrm{OM}$ & $\mathrm{mC}_{\mathrm{d}}$ \\
\hline $\mathrm{Zn}$ & 1 & & & & & & & & \\
$\mathrm{Cu}$ & .025 & 1 & & & & & & & \\
$\mathrm{~Pb}$ & $.510^{* *}$ & .331 & 1 & & & & & & & \\
$\mathrm{Ni}$ & $.406^{*}$ & $.573^{* *}$ & $.415^{*}$ & 1 & & & & & & \\
$\mathrm{Mn}$ & .017 & $-.424^{*}$ & -.208 & -.212 & 1 & & & & & \\
$\mathrm{Cr}$ & $.616^{* *}$ & .096 & $.444^{*}$ & $.513^{* *}$ & .045 & 1 & & & \\
$\mathrm{Co}$ & $.779^{* *}$ & -.264 & .333 & .260 & .251 & $.480^{* *}$ & 1 & & \\
$\mathrm{Fe}$ & -.220 & -.059 & -.273 & -.053 & .343 & -.163 & -.036 & 1 & \\
$\mathrm{OM}$ & -.266 & .046 & $-.454^{*}$ & -.166 & .044 & $-.510^{* *}$ & -.282 & $.377^{*}$ & 1 & \\
$\mathrm{mC}$ & $.766^{* *}$ & .335 & $.627^{* *}$ & $.761^{* *}$ & .086 & $.752^{* *}$ & $.697^{* *}$ & .058 & -.319 & 1 \\
\hline
\end{tabular}

${ }^{* *}$ Correlation is significant at the 0.01 level (2-tailed)

*Correlation is significant at the 0.05 level (2-tailed) 
strongly correlated with $\mathrm{mC}_{\mathrm{d}}(r=0.761$ for $\mathrm{Ni}, r=0.752$ for $\mathrm{Cr} ; p=0.01)$. Co has significant positive correlation with $\mathrm{mC}_{\mathrm{d}}(r=0.697 ; p=0.01)$. Organic matter has moderate positive correlation with $\mathrm{Fe}(r=0.337 ; p>0.05)$ and poor positive correlations with $\mathrm{Cu}$ and $\mathrm{Mn}$. It has significant negative correlation with $\mathrm{Cr}(r=-0.510 ; p>0.01)$ and moderate negative correlation with $\mathrm{Pb}$.

\subsection{Sediment quality guidelines}

The quality of lake sediments can be assessed by comparing their heavy metal contents with sediment quality guidelines (SQGs) to reveal the threshold metal contamination and their adverse effects on the sediment-dwelling organisms [39]. The heavy metal concentrations in Loktak sediments were compared with two categories of SQGs for freshwater ecosystems such as effect range-low (ERL) and effect range-median (ERM). Both the guidelines define three effect ranges, i.e., metal concentrations below the ERL value would unlikely give undesirable effects on the sediment-dwelling organisms whereas above the ERM value would likely contribute frequent undesirable effects and between the range of ERL and ERM contribute undesirable effects occasionally [5]. The concentration of $\mathrm{Pb}$ is lower than the ERL value (except the sample at site 28 from the Moirang River inlet that has higher Pb concentration than that of ERL), so its effect on the sedimentdwelling organisms will unlikely occur (Table 3 ). Samples at sites 2, 5, 11, 12, 21, 22 and 23 have $Z n$ concentrations slightly above the ERL and samples at sites 1, 10 and 28 are relatively higher than that of ERL. Samples of 12 have Cu concentrations little above the ERL value and the rest are below the ERL value. The concentrations of $\mathrm{Ni}$ and $\mathrm{Cr}$ of all the samples are higher than that of respective ERMs suggesting the likely occurrence of toxic effects on the sediment-dwelling biota.

The mean-ERM-quotient (M-ERM-Q) of $<0.10$, $0.11 \leq \mathrm{M}-$ ERM-Q $<0.50,0.51 \leq \mathrm{M}-\mathrm{ERM}-\mathrm{Q}<1.5$ and $>1.5$ suggest $9 \%, 21 \%, 49 \%$ and $76 \%$, respectively, of toxic probability [38]. The corresponding potentials of toxicity are low, medium-low, medium-high and high, respectively [70]. M-ERM-Q was calculated with 5 heavy metals such as $\mathrm{Zn}, \mathrm{Cu}, \mathrm{Pb}, \mathrm{Ni}$ and $\mathrm{Cr}$ since SQGs have no recommended ERMs set for $\mathrm{Fe}, \mathrm{Mn}$ and $\mathrm{Co}$ [39]. The calculated values range from 1.02 to 1.95 with a mean of 1.32 (Fig. 5) (Supplementary data are provided by Table S3). Samples of 2 (at sites 4 and 23 from nearby Thanga Island and northeastern portion of the lake, respectively) have values slightly above 1.5 and the sample at 28 from Moirang River inlet has M-ERM-Q value way above 1.5. They suggest $76 \%$ of toxic probability, while the rest have values within the range of 0.51 and 1.5 suggesting $49 \%$ of toxic probability. The result suggests that the majority of samples have a medium-high potential for heavy metal toxicity on the biotic population. It is mainly because of the high concentration of $\mathrm{Ni}$ and $\mathrm{Cr}$ in the lake sediments. The input of heavy metals into the lake needs to be monitored particularly $\mathrm{Ni}$ and $\mathrm{Cr}$ since their contaminations may impose biological risks as indicated by respective ERMs of the SQGs.

\section{Conclusions}

Studies on the mineralogy, major oxide compositions and the heavy metal pollution status of surface sediments of freshwater Loktak Lake were carried out. The sediments are non-calcareous and rich in organic matter (7.1-32.7 wt\%). The XRD spectra of bulk sediments show the dominance of quartz, while smectite, kaolinite, mica, chlorite and hematite are also found. Clay fractions show the dominance of illite and chlorite and kaolinite, smectite and mica are also observed. The major oxides have relatively lower contents of $\mathrm{SiO}_{2}, \mathrm{~K}_{2} \mathrm{O}, \mathrm{MgO}, \mathrm{CaO}$ and $\mathrm{Na}_{2} \mathrm{O}$ and a higher concentration of $\mathrm{FeO}$ than corresponding UCC, PAAS and NASC. The relatively higher $\mathrm{FeO}$ and lower $\mathrm{SiO}_{2}$ contents in sediments suggest the
Fig. 5 Classification of samples based on M-ERM-Q

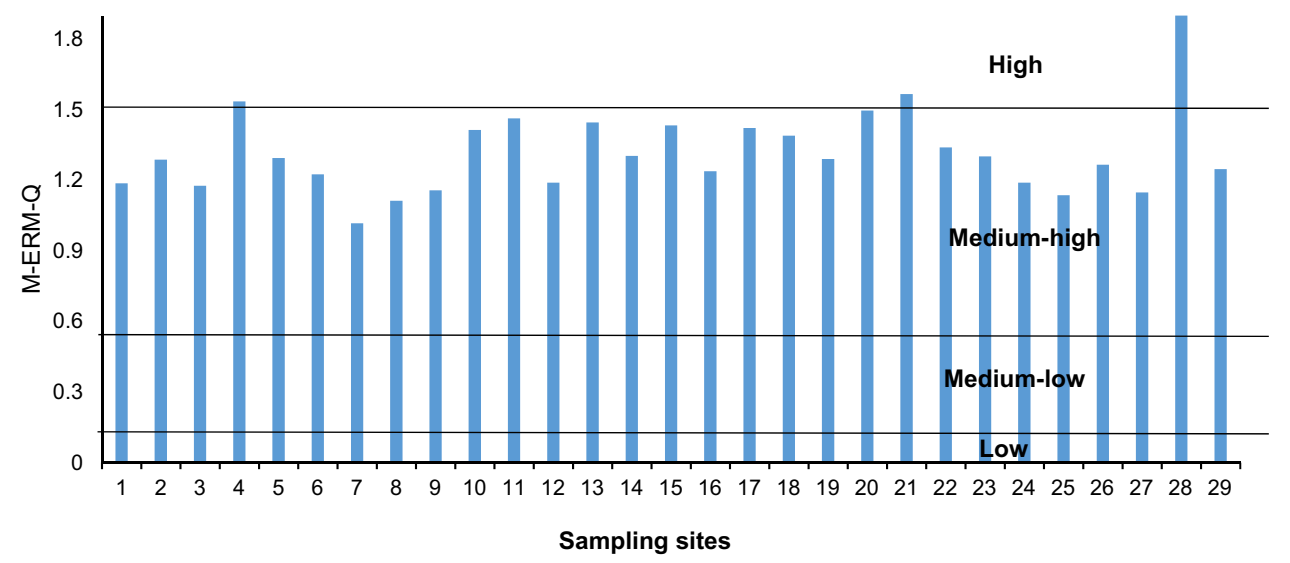

SN Applied Sciences A SPRINGER NATURE journal 
involvement of mafic rock sources. The low contents of labile elements such as $\mathrm{Ca}, \mathrm{Na}$ and $\mathrm{K}$ indicate high intensity weathering of the catchment area. The high $\mathrm{CIA}$ (76.86-84.98) also indicates moderate to extreme chemical weathering of the lithologies in the catchment area. The higher concentrations of $\mathrm{Al}_{2} \mathrm{O}_{3}$, high LOI and $\mathrm{CIA}$ values are consistent with the clay-rich nature of the sediments. Except for $\mathrm{Mn}$ and $\mathrm{Pb}$, the mean concentrations of heavy metals are about 2-4 times higher than that of UCC and they follow the trend of $\mathrm{Fe}>\mathrm{Mn}>\mathrm{Cr}>$ $\mathrm{Ni}>\mathrm{Zn}>\mathrm{Cu}>\mathrm{Co}>\mathrm{Pb}$.

The EF and $l_{\text {geo }}$ indicated the heavy metal pollution of Loktak sediments ranging from non-pollution to moderate pollution. $\mathrm{mC}_{\mathrm{d}}$ indicated the moderate degree of contamination in the majority of the Loktak sediments. The M-ERM- $\mathrm{Q}$ for heavy metals ( $\mathrm{Zn}, \mathrm{Cu}, \mathrm{Pb}, \mathrm{Ni}$ and $\mathrm{Cr}$ ) suggested medium-high to high potential in their impacts on the biotic population. The relatively higher concentration of heavy metals in general and $\mathrm{Ni}$ and $\mathrm{Cr}$, in particular, indicated an ophiolitic (ultramafic rocks) source with no or little, if any, anthropogenic influence. The remedial measures should include regular checking of waste disposal, monitoring of anthropogenic activities by communities in the direct and indirect catchment area and fertilizer application in agricultural fields located around Loktak Lake. There should be afforestation and reduced shifting cultivation in the catchment particularly in the hills and pre-treatment of effluents before reaching the lake.

Acknowledgement We thank the Dean, School of Environmental Sciences, Jawaharlal Nehru University for encouragement and Department of Science and Technology (Purse-Phase-II) and University Grant Commission (UPE) for financial support. The authors thank the anonymous reviewers for constructive reviews and valuable suggestions that helped in improving the quality of this paper.

\section{Compliance with ethical standards}

Conflict of interest The authors declare that they have no conflict of interest.

\section{References}

1. Abrahim GMS, Parker RJ (2008) Assessment of heavy metal enrichment factors and the degree of contamination in marine sediments from Tamaki Estuary, Auckland, New Zealand. Environ Monit Assess 136(1-3):227-238. https://doi.org/10.1007/s1066 1-007-9678-2

2. Arain MB, Kazi TG, Jamali MK, Jalbani N, Afridi HI, Shah A (2008) Total dissolved and bioavailable elements in water and sediment samples and their accumulation in Oreochromis mossambicus of polluted Manchar Lake. Chemosphere 70:1845-1856

3. Bibi MH, Ahmed F, Ishiga $H$ (2007) Assessment of metal concentrations in lake sediments of southwest Japan based on sediment quality guidelines. Enviro Geol 52(4):625-639
4. Bifano C, Mogollbn JL (1995) Metallic contaminant profiles in sediment cores from Lake Valencia, Venezuela. Environ Geochem Health 17:113-118

5. Budur AA, Ines EM, Sami AZ (2019) Heavy metals' contamination in sediments of Wadi Al-Aqiq water reservoir dam at Al-Baha region, KSA: their identification and assessment. Hum Ecol Risk Assess 25(4):793-818

6. Carroll D (1970) Rock weathering. Plenum Press, New York, p 203

7. Cevik F, Goksu MZL, Derici OB, Fındık O (2009) An assessment of metal pollution in surface sediments of Seyhan dam by using enrichment factor, geoaccumulation index and statistical analyses. Environ Monit Assess 152:309-317

8. Chakrapani GJ (2002) Water and sediment geochemistry of Major Kumaun Himalayan Lakes, India. Environ Geol 43:99-107

9. Chen CW, Kao CM, Chen CF, Dong CD (2007) Distribution and accumulation of metals in sediments of Kaoshiung Harbor Taiwan. Chemosphere 66:1431-1440

10. Das BK, Haake BG (2003) Geochemistry of Rewalsar Lake sediment, Lesser Himalaya, India: implications for sourcearea weathering, provenance and tectonic setting. Geosci J 7(4):299-312

11. Das BK, Gaye B, Kaur P (2008) Geochemistry of Renuka Lake and wetland sediments, Lesser Himalaya (India): implications for source-area weathering, provenance, and tectonic setting. Environ Geol 54(1):147-163

12. Das S, Choudhury SS (2016) Analysis of heavy metals from water, sediment, and tissues of Labeo angra (Hamilton, 1822), from an Ox-box lake- a wetland site from Assam, India. J Environ Sci Health A 51(1):21-23

13. Devi MB, Devi OS, Singh SD (2013) Preliminary study of aquatic insect diversity and water quality of Loktak Lake, Manipur. Int J Int sci Inn Tech Sec C 2(3):33-37

14. Ebrahimpour M, Mushrifah I (2008) Heavy metal concentrations in water and sediments in Tasik Chini, a freshwater lake Malaysia. Environ Monit Assess 141(1-3):297-307

15. El-Amier YA, Elnaggar AA, El-Alfy MA (2017) Evaluation and mapping spatial distribution of bottom sediment heavy metal contamination in Burullus Lake Egypt. Egypt J Basic Appl Sci 4:55-66

16. Geeta OD, Khuswaha RAS, Okendro M (2006) Trace element contamination in Loktak Lake Manipur. In: Saklani PS (ed) Himalaya geological aspects. Satish Serial Publishing House, New Delhi, pp 313-324

17. Ghrefat HA, Abu-Rukah Y, Rosen MA (2011) Application of geoaccumulation index and enrichment factor for assessing metal contamination in the sediments of Kafrain Dam, Jordan. Environ Monit Assess 178:95-109. https://doi.org/10.1007/s1066 1-010-1675-1

18. Goher ME, Farhat HI, Abdo MH, Salem SG (2014) Metal pollution assessment in the surface sediment of Lake Nasser, Egypt. Egypt J Aquat Res 40:213-224

19. Gopal V, Achyuthan H, Jayaprakash M (2017) Assessment of trace elements in Yercaud Lake sediments, southern India. Environ Earth Sci 76(2):63

20. Gromet LP, Dymek RF, Haskin LA, Korotev RL (1984) The North American Shale composite: its compilation, major and trace element characteristics. Geochimica et Cosmochinica Acta 48(12):2469-2482

21. Gulson BL, Davis JJ, Mizon KJ, Korsch MJ, Bawden-Smith J (1995) Sources of lead in soil and dust and the use of dust fallout as a sampling medium. Sci Total Environ 166(1):245-262. https://doi. org/10.1016/0048-9697(95)04505-U

22. Guo B, Liu Y, Zhang F, Hou J, Zhang H, Li C (2018) Heavy metals in the surface sediments of lakes on the Tibetan Plateau, China. Environ Sci Pollut Res 25:3695-3707. https://doi.org/10.1007/ s11356-017-0680-0 
23. Guo H, Yang L, Han X, Dai J, Pang X, Ren M, Zhang W (2019) Distribution characteristics of heavy metals in surface soils from the western area of Nansi Lake, China. Environ Monit Assess 191:262. https://doi.org/10.1007/s10661-019-7390-7

24. Gupta S (2012) Lake Loktak in Manipur, North East India: Major issues in conservation and management of a Ramsar Site. Bionano Frontier. Eco Revolution, Columbo, Sri Lanka

25. Hakanson $L$ (1980) An ecological risk index for aquatic pollution control, a sedimentological approach. Water Res 14:975-1001

26. Hu C, Deng Z, Xie Y, Chen X, Li F (2015) The risk assessment of sediment heavy metal pollution in the East Dongting Lake Wetland. J Chem 835487:8. https://doi.org/10.1155/2015/835487

27. Iqbal J, Shah MH (2014) Occurrence, risk assessment, and source apportionment of heavy metals in surface sediments from Khanpur Lake, Pakistan. J Anal Sci Technol 5:28

28. Jeelani G, Shah AQ (2006) Geochemical characteristics of water and sediment from the Dal Lake, Kashmir Himalaya: constraints on weathering and anthropogenic activity. Environ Geol 50(1):12-23

29. Kabata-Pendias A, Mukherjee AB (2007) Trace elements from soil to human. Springer, Berlin

30. Kabata-Pendias A, Pendias H (2001) Trace elements in soils and plants, 3rd edn. CRC Press, Boca Raton

31. Kangabam RD, Boominathan SD, Govindaraju M (2015) Ecology, disturbance and restoration of Loktak Lake in Indo-Burma Biodiversity Hotspot-an overview. NeBIO-An Int J Environ Biodivers 6(2):9-15

32. Kangabam RD, Selvaraj M, Govindaraju M (2018) Spatio-temporal analysis of floating islands and their behavioral changes in Loktak Lake with respect to biodiversity using remote sensing and GIS techniques. Environ Monit Assess 190:118. https://doi. org/10.1007/s10661-018-6485-x

33. Khalil MK, Radwan AM, El-Moselhy KM (2007) Distribution of phosphorus fractions and some of heavy metals in surface sediments of Burullus lagoon and adjacent Mediterranean Sea. Egypt J Aquat Res 33(1):277-289

34. Last WM (2002) Mineralogical analysis of lake sediments. In: Tracking environmental change using lake sediments. Springer, Dordrecht

35. Lindholm RC (1987) A practical approach to sedimentology. Allen and Unwin Inc., London

36. Lone A, Babeesh C, Achyuthan H, Chandra R (2017) Evaluation of environmental status and geochemical assessment of sediments, Manasbal Lake, Kashmir, India. Arab J Geosci 10:92. https ://doi.org/10.1007/s12517-016-2826-7

37. Lone AM, Shah RA, Achyuthan H, Fousiya AA (2018) Geochemistry, spatial distribution and environmental risk assessment of the surface sediments: Anchar Lake, Kashmir Valley India. Environ Earth Sci 77(3):65

38. Long ER, MacDonald DD, Severn CG, Hong CB (2000) Classifying the probabilities of acute toxicity in marine sediments with empirically-derived sediment quality guidelines. Environ Toxicol Chem 19:2598-2601

39. MacDonald DD, Ingersoll CG, Berger TA (2000) Development and evaluation of consensus-based sediment quality guidelines for freshwater ecosystems. Arch Environ Contam Toxicol 39:20-31

40. Mahamood MD, Sufyan N, Ahmad I (2014) Nematodes of Loktak Lake, the only Ramsar Site in northeastern India. Physicochemical properties of soil and water and first report on diversity and community analysis of nematodes. Int J Adv Life Sci 3(1):27-32

41. Mayanglambam B, Neelam SS (2018) Lake morphometry and the distribution of macrophytes in Loktak Lake, Manipur, India. ENVIS RP. Geodiversity Impact Environ 23(4):1-16

42. Mayanglambam B, Neelam SS (2020) Physicochemistry and water quality of Loktak Lake water Manipur, India. Int J Environ Anal Chem. https://doi.org/10.1080/03067319.2020.1742888
43. McLennan SM (2001) Relationship between the trace element composition of sedimentary rocks and upper continental crust. Geochem Geophys Geosyst. https://doi. org/10.1029/2000GC000109

44. Meitei MD, Prasad MNV (2015) Phoomdi-a unique plant biosystem of Loktak lake, Manipur, North-East India: traditional and ecological knowledge. Plant Biosyst 149(4):777-787. https ://doi.org/10.1080/11263504.2013.870250

45. Meitei MD, Prasad MNV (2016) Bioaccumulation of nutrients and metals in sediment, water, and phoomdi from Loktak Lake (Ramsar site), northeast India: phytoremediation options and risk assessment. Environ Monit Assess 188:329

46. Mitre V, Prasad VK, Guha PK (1986) Technical report by members of multidisciplinary survey of the Loktak Lake submitted to the Government of Manipur in 1981

47. Muller G (1969) Index of geoaccumulation in sediments of the Rhine River. GeoJournal 2:108-118

48. Mushtaq B, Raina R, Yousuf AR, Wanganeo A, Shafi N, Manhas A (2015) Chemical characteristics of bottom sediments of Dal Lake Srinagar, Kashmir. J Environ Prot Sustain Dev 1(1):1-7

49. Nair V, Achyuthan H (2017) Geochemistry of Vellayani lake sediments: indicators of weathering and provenance. J Geol Soc India 89(1):21-26

50. Nesbitt HW, Young GM (1982) Early proterozoic climates and plate motions inferred from major element chemistry of lutites. Nature 199:715-717

51. NRC (National Research Council) (1989) Contaminated marine sediments-assessment and remediation. National Academy Press, National Research Council, p 493

52. Pejman A, Bidhendi GN, Ardestani M, Saeedi M, Baghvand A (2015) A new index for assessing heavy metals contamination in sediments: a case study. Ecol Indic 58:365-373

53. Roy PD, Caballero M, Lozano R, Smykatz-Kloss W (2008) Geochemistry of late quaternary sediments from Tecocomulco lake, central Mexico: implication to chemical weathering and provenance. Geochemistry 68(4):383-393

54. Roy R, Majumder M (2019) Assessment of water quality trends in Loktak Lake, Manipur, India. Environ Earth Sci 78:383

55. Sarkar D, Baruah U, Gangopadhyay SK, Sahoo AK, Velayutham M (2002) Characteristics and classification of soils of Loktak catchment area of Manipur for sustainable land use planning. J Indian Soc Soil Sci 50(2):196-204

56. Santisteban JI, Mediavilla R, López-Pamo E, Dabrio CJ, Zapata MBR, García MJG, Castaño S, Martínez-Alfaro PE (2004) Loss on ignition: a qualitative or quantitative method for organic matter and carbonate mineral content in sediments? J Paleolimnol 32(3):287-299

57. Selvam AP, LaxmiPriya S, Kakolee B, Hariharan G, Purvaja R, Ramesh R (2012) Heavy metal assessment using geochemical and statistical tools in the surface sediments of Vembanad Lake, southwest coast of India. Environ Monit Assess 184:5899-5915

58. Shapiro L, Brannock WW (1962) Rapid analyses of silicate, carbonate and phosphate rocks. U.S. Geol Surv Bull 48:49-55

59. Sharma BR (2009) Composition, abundance and ecology of phytoplankton communities of Loktak Lake, Manipur, India. J Threat Taxa 1(8):401-410

60. Sheikh JA, Jeelani G, Gavali RS, Shah RA (2014) Weathering and anthropogenic influences on the water and sediment chemistry of Wular Lake, Kashmir Himalaya. Environ Earth Sci 71:28372846. https://doi.org/10.1007/s12665-013-2661-z

61. Singh AL, Moirangleima K (2009) Shrinking Water area in the wetlands of the central valley of Manipur. Open Renew Energy J 2:1-5. https://doi.org/10.2174/1876387100902010001

62. Singh RH (2004) Tectonic significance of minor structures of the rocks of Imphal Valley. Dissertation, Manipur University 
63. Singh HT, Singh RKS (1994) Ramsar sites of India Loktak Lake Manipur. Work Wide Fund for Nature, India, p 23

64. Singh KJ, Sarkar S (2013) Development of GIUH for the catchment contributing to Loktak Lake, North East India. J Indian Soc Remote Sens 41(2):447-459

65. Singh NS, Devi CB, Sudarshan M, Meetei NS, Singh TB, Singh NR (2013) Influence of Nambul River on the quality of fresh water in Loktak Lake. Int J Water Res Environ Eng 5(6):321-327

66. Soibam I, Khuman MCh, Subhamenon SS (2015) Ophiolitic rocks of the Indo-Myanmar Ranges, NE India: relicts of an inverted and tectonically imbricated hyper-extended continental margin basin, geological society. Special Publications, London

67. Srivastava P, Siddaiah NS, Sangode SJ, Meshram DC (2018) Mineralogy and geochemistry of various colored boles from the Deccan volcanic province: implications for paleoweathering and paleoenvironmental conditions. CATENA 167:44-59

68. Taylor SR, McLennon SM (1985) The continental crust: its composition and evolution. Backwell Scientific Publication Ltd., Hoboken

69. Tripathi S, Singh YR, Nautiyal CM, Thakur B (2018) Vegetation history, monsoonal fluctuations and anthropogenic impact during the last 2330 years from Loktak Lake (Ramsar site), Manipur, north-east India: a pollen based study. Palynology 42(3):406-419
70. Violintzis C, Arditsoglou A, Voutsa D (2009) Elemental composition of suspended particulate matter and sediments in the coastal environment of Thermaikos Bay, Greece: delineating the impact of inland waters and wastewaters. J Hazard Mater $166: 1250-1260$

71. WISA, LDA (2004) Atlas of Loktak Lake, Wetlands InternationalSouth Asia and Loktak development authority, Imphal

72. Xie Z, Jiang Y, Zhang H, Wang D, Qi S, Du Z, Zhang H (2016) Assessing heavy metal contamination and ecological risk in Poyang Lake area China. Environ Earth Sci 75:549

73. Zahra A, Hashmi MZ, Malik RN, Ahmed Z (2014) Enrichment and geo-accumulation of heavy metals and risk assessment of sediments of the Kurang Nallah-feeding tributary of the Rawal Lake Reservoir, Pakistan. Sci Total Environ 470:925-933

74. Zhang C, Yu ZG, Zeng GM, Jiang M, Yang ZZ, Cui F, Zhu MY, Shen LQ, Hu L (2014) Effects of sediment geochemical properties on heavy metal bioavailability. Environ Int 1(73):270-281

Publisher's Note Springer Nature remains neutral with regard to jurisdictional claims in published maps and institutional affiliations. 